\title{
PENGARUH LAMA PERENDAMAN DALAM AIR PERASAN BUAH BELIMBING WULUH (Averrhoa bilimbi Linn) DAN LAMA PENYIMPANAN TERHADAP KARAKTERISTIK IKAN TONGKOL (Euthynnus affinis) PADA SUHU RUANG
}

\author{
Yemima Maria Lasmaroha Sitompul ${ }^{1)}$, I Made Sugitha ${ }^{2)}$, Agus Selamet Duniaji ${ }^{2}$ \\ ${ }^{1)}$ Mahasiswa Program Studi Ilmu dan Teknologi Pangan, Fakultas Teknologi Pertanian, Unud \\ ${ }^{2)}$ Dosen Program Studi Ilmu dan Teknologi Pangan, Fakultas Teknologi Pertanian, Unud \\ Kampus Bukit Jimbaran, Badung-Bali
}

\begin{abstract}
This study aims to find out the effect of immersion time in wuluh starfruit juice (Averrhoa bilimbi) and storage time of characteristics mackarel tuna fish (Euthynnus affinis), as well as to determine the right time of immersion in wuluh starfruit juice and storage time to produce mackarel tuna fish with still acceptable characteristics. The experimental design used in this study was a Completely Randomized Design with 5 level immersion treatments, namely: 0 minutes, 2 minutes, 4 minutes, 6 minutes, and 8 minutes, with the observation time in the 3 and 6 hour. The treatment was repeated 2 times to obtain 20 experimental units. The data obtained were analyzed by variance and if the treatment had an effect on the observed variables then it was continued with the Duncan test. The results of the study with duration of immersion time that produced with still acceptable mackarel tuna fish products was 4 minutes at the time of observation of the 6 hour the water content is $71,5 \%$, the acidity was 5.35 , the microbial total was $4,28 \log \mathrm{cfu} / \mathrm{g}$ or $1.9 \times 10^{4} \mathrm{cfu} / \mathrm{g}$, and the total volatile base was 21,57 mg N / 100g which was low and the score of color, smell, texture and scales, the eyes, gills, and body surface mucus can be accepted by the panelists as well as overall acceptance that was preferred.
\end{abstract}

Keywords : mackarel tuna fish, wuluh starfruit, immersion time, storage time, total volatil base

\section{PENDAHULUAN}

Ikan tongkol (Euthynnus affinis) adalah ikan yang berpotensi cukup tinggi dengan kandungan gizi yang lengkap yang mana nilai proteinnya mencapai $26 \%$, kadar lemak rendah yaitu $2 \%$,mengandung asam lemak omega-3, dan kandungan garam-garam mineral penting yang tinggi (Djuhanda, 1981). Ikan tongkol banyak disukai masyarakat dan memiliki nilai yang ekonomis. Menurut Djaafar (2007), ikan memiliki kandungan gizi yang cukup tinggi, tetapi ikan merupakan sumber pangan yang mudah rusak karena sangat cocok untuk pertumbuhan mikroba baik patogen maupun non-patogen,.

Menurut Jayanti et al., (2012), aplikasi penggunaan es dianggap masih memiliki masalah terutama ketidakpraktisan karena es yang mudah mencair jika tidak menggunakan wadah yang berinsulasi. Dewasa ini juga, banyak perlakuan dalam proses penanganan yang salah, yaitu dengan mencampurkan bahanbahan pengawet sintesis, karena memiliki harga yang murah dan mudah diperoleh. Namun, berbahaya bagi kesehatan (Siti, 2018). Bahan pengawet alami adalah bahan tambahan yang diberikan pada makanan yang biasanya berasal dari tumbuhan, hewan maupun mikroba (Meliya, 2018).

Yusni (2014), menyatakan belimbing wuluh merupakan sejenis tanaman yang banyak mengandung asam, yang berfungsi sebagai antimikroba. Zat asam dapat membuat metabolisme bakteri menjadi terganggu. Kondisi asam akan membuat banyak bakteri tidak bermetabolisme (tidak beradaptasi dengan baik pada suasana asam) sehingga tidak terjadi pertumbuhan bakteri (Yusni, 2014).

Beberapa asam organik antara lain, asam asetat, sitrat, format, laktat, dan oksalat (Aminonatalia, 2016). Selain itu, belimbing wuluh mengandung banyak vitamin $\mathrm{C}$ alami yang berguna sebagai penambah daya tahan tubuh dan perlindungan terhadap berbagai penyakit. Belimbing wuluh juga mengandung

Korespondensi Penulis :

E-mail : yemimasitompul36@ gmail.com ${ }^{1)}$ 
vitamin dan mineral lain, yaitu ribovlavin, vitamin $\mathrm{B} 1$, niasin, asam askorbat, vit $\mathrm{A}$, sedangkan mineralnya antara lain phosphor, kalsium dan besi (Diah, 2014).

Adapun tujuan penelitian ini untuk mengetahui pengaruh lama perendaman dalam air perasan buah belimbing wuluh, dan lama penyimpanan terhadap karakteristik ikan tongkol dan untuk mengetahui lama perendaman dalam air perasan buah belimbing wuluh dan lama penyimpanan yang tepat untuk menghasilkan ikan tongkol dengan karakteristik yang masih dapat diterima.

\section{METODE PENELITIAN}

\section{Tempat dan Waktu}

Penelitian ini dilaksanakan di Laboratorium Mikrobiologi Pangan, Laboratorium Pengolahan Pangan, Laboratorium Analisis Pangan Teknologi Pertanian, Universitas Udayana dan Laboratorium Analisis Mutu Dinas Perikanan Provinsi Bali. Waktu pelaksanaan pada bulan Maret sampai dengan Mei 2019.

\section{Bahan dan Alat}

Bahan yang digunakan dalam melaksanakan penelitian ini yaitu ikan tongkol (Euthynnus affinis, buah belimbing wuluh. $\mathrm{NaOH}, \mathrm{H}_{3} \mathrm{BO}_{3}, \mathrm{HCl}$ $0,02 \mathrm{~N}$, asam perklorat $\left(\mathrm{HClO}_{4}\right)$, Plate Count Agar (PCA), $\mathrm{NaCl}$, akuades, alkohol $70 \%$.

Alat yang digunakan adalah cool box sebanyak 1 buah, berukuran $40 \mathrm{~cm} \times 30 \mathrm{~cm}$ $\mathrm{x} 29 \mathrm{~cm}$, lembar score sheet ikan segar (SNI-01-2346-2006), kemasan mika berukuran $54 \mathrm{~cm}-60 \mathrm{~cm}$, talenan, baskom, penggaris, saringan, alumunium foil, timbangan, blender (Miyako), thermometer, vortex, pipet volume, botol kaca, kertas saring, corong, inkubator, cawan petri (Pyrex), pipet mikro, desikator, biuret, tabung reaksi (Pyrex), erlenmeyer (Pyrex), gelas ukur (Pyrex), oven, laminar flow, $\mathrm{pH}$ meter.

\section{Pelaksanaan Penelitian}

Pelaksanaan penelitian terdiri dari beberapa tahap yaitu:

\section{Persiapan Ikan Tongkol}

Bahan baku berupa ikan tongkol (Euthynnus affinis) yang diperoleh dari salah seorang nelayan perairan Desa Kedonganan, Kecamatan Kuta, Kabupaten Badung, Bali. Ikan tongkol segar ditimbang terlebih dahulu lalu dimasukkan kedalam cooler box yang berisi es, ikan tongkol yang telah dipersiapkan (ukuran $38-50 \mathrm{~cm}$ ) kemudian diberikan perlakuan pendahuluan berupa pencucian dan pembersihan pada daging ikan

\section{Persiapan Buah Belimbing Wuluh}

Buah belimbing wuluh diperoleh dari pohon secara langsung di Desa Jimbaran, Kecamatan Kuta Selatan, Kabupaten Badung, Bali. Buah belimbing wuluh yang telah dipersiapkan (warna hijau, ukuran 3$5 \mathrm{~cm}$ ) ditimbang terlebih dahulu, lalu diberikan perlakuan pendahuluan berupa pencucian kemudian dihancurkankan lalu disaring sehingga diperoleh air perasan buah belimbing wuluh.

\section{Perendaman}

Air perasan buah belimbing wuluh yang dipersiapkan dituangkan pada wadah (ukuran $34-50 \mathrm{~cm}$ ), kemudian ikan tongkol yang telah dipersiapkan direndam pada air perasan buah belimbing wuluh dengan lama perendaman yang berbeda.

Kemudian ditiriskan dan disimpan pada suhu ruang dan dilakukan pengamatan pada jam ke-3 dan jam ke-6. Dilakukan pengujian sesuai dengan parameter yang diamati, yaitu kadar air, nilai $\mathrm{pH}$, TPC (Total Plate Count), TVB (Total Volatil Base), warna, bau, tekstur dan sisik, keadaan mata, insang, lendir permukaan badan, dan penerimaan keseluruhan. 


\section{Rancangan Percobaan dan Analisis Data}

Rancangan yang digunakan pada penelitian ini adalah Rancangan Acak Lengkap Faktorial (RALF) yang terdiri dari dua faktor yaitu, Faktor 1 lama perendaman A1(tanpa perendaman asam), A2 (2 menit), A3 (4 menit), A4 (6 menit), dan A5 (8 menit). Faktor 2 lama penyimpanan P1 (3 jam) dan P2 (6 jam). Masing-masing diulang sebanyak 2 kali sehingga diperoleh 20 unit percobaan.

Data yang dihasilkan kemudian dianalisis dengan analisis ragam pada program SPSS dan apabila terdapat pengaruh perlakuan terhadap parameter yang diamati, maka dilanjutkan dengan uji Duncan (Gomez and Gomes, 1995)

\section{Parameter yang Diamati}

Parameter yang akan diamati yaitu kadar air (Sudarmadji dkk., 1997), pH (Aufar, 2012), total mikroba (SNI 23462015), total volatil base (SNI 2354.8:2009) dan organoleptik (Hadiwiyoto, 1993) meliputi uji skoring warna, bau, tekstur dan sisik, keadaan mata, keadaan insang, dan lendir permukaan badan dan uji hedonik yaitu penerimaan keseluruhan.

\section{HASIL DAN PEMBAHASAN}

bahwa perlakuan lama perendaman berpengaruh nyata $(\mathrm{P}<0,05)$, sedangkan lama penyimpanan dan interaksi antar kedua perlakuan tidak berpengaruh nyata $(\mathrm{P}>0,05)$ terhadap kadar air ikan tongkol yang dihasilkan yang direndam dalam air perasan belimbing wuluh.

Tabel 1 menunjukkan bahwa nilai rata-rata kadar air yang dihasilkan pada perlakuan lama perendaman diperoleh kadar air tertinggi pada perlakuan A1 yaitu sebesar $72,25 \%$, sedangkan nilai rata-rata terendah pada perlakuan A5 yaitu sebesar $70 \%$. Pengaruh lama perendaman terhadap kadar air ikan tongkol dalam Tabel 1 dapat dilihat semakin lama perendaman, maka kadar air ikan tongkol semakin menurun.
Hal ini disebabkan semakin meningkatnya kandungan asam seiring lama perendaman terjadi denaturasi protein, mengakibatkan gugus samping protein terbuka dan kelarutan protein semakin menurun sehingga protein terpisah sebagai endapan menyebabkan penurunan kemampuan dalam mengikat air sehingga air terperas keluar ((Brogstrom, 1995).

Tabel 1. Nilai rata-rata Kadar air ikan tongkol yang direndam dalam air perasan belimbing wuluh.

\begin{tabular}{cccc}
\hline \multirow{2}{*}{$\begin{array}{c}\text { Lama } \\
\text { Perend } \\
\text { aman }\end{array}$} & \multicolumn{2}{c}{ Lama Penyimpanan } & Rata-rata \\
\cline { 2 - 3 } & $\mathrm{P} 1$ & $\mathrm{P} 2$ & \\
\hline $\mathrm{A} 1$ & $72,00 \pm 1,41$ & $72,50 \pm 0,70$ & $72,25 \pm 0,95 \mathrm{a}$ \\
$\mathrm{A} 2$ & $71,50 \pm 0,70$ & $72,00 \pm 1,41$ & $71,75 \pm 0,95 \mathrm{ab}$ \\
$\mathrm{A} 3$ & $71,00 \pm 0,00$ & $71,50 \pm 0,70$ & $71,25 \pm 0,50 \mathrm{ab}$ \\
$\mathrm{A} 4$ & $70,50 \pm 0,70$ & $71,00 \pm 0,00$ & $70,75 \pm 0,50 \mathrm{bc}$ \\
$\mathrm{A} 5$ & $70,00 \pm 0,00$ & $70,00 \pm 0,00$ & $70,00 \pm 0,00 \mathrm{c}$ \\
\hline Rata- & $71,00 \pm 0,94$ & $71,40 \pm 1,07$ \\
rata & & \\
\hline Keterangan : Nilai rata-rata yang diikuti oleh huruf \\
\multicolumn{4}{c}{ yang sama pada kolom yang sama } \\
& menunjukkan perbedaan tidak nyata \\
pada Uji Duncan (P>0,05).
\end{tabular}

Tabel 1 menunjukkan bahwa nilai rata-rata kadar air yang direndam dalam air perasan belimbing wuluh masih memenuhi standard kandungan gizi kadar air ikan tongkol yaitu sebesar 72\% (Anonim, 1972).

\section{Uji Derajat Keasaman (pH)}

Hasil sidik ragam menunjukkan perlakuan lama perendaman dan lama penyimpanan berpengaruh nyata $(\mathrm{P}<0,05)$, sedangkan interaksi antar kedua perlakuan tidak berpengaruh nyata $(\mathrm{P}>0,05)$ terhadap nilai $\mathrm{pH}$ ikan tongkol yang direndam dalam air perasan belimbing wuluh.

Tabel 2 menunjukkan nilai rata-rata lama perendaman tertinggi diperoleh pada perlakuan A1 yaitu sebesar 5,52, sedangkan nilai rata-rata terendah diperoleh pada perlakuan A5 yaitu sebesar 5,15 . 
Tabel 2. Nilai rata-rata $\mathrm{pH}$ ikan tongkol yang dalam air perasan belimbing wuluh

\begin{tabular}{cccc}
\hline $\begin{array}{c}\text { Lama } \\
\text { Perend } \\
\text { aman }\end{array}$ & \multicolumn{2}{c}{ Lama Penyimpanan } & Rata-rata \\
\cline { 2 - 3 } & P1 & P2 & \\
\hline A1 & $5,50 \pm 0,00$ & $5,55 \pm 0,07$ & $5,52 \pm 0,05 \mathrm{a}$ \\
$\mathrm{A} 2$ & $5,50 \pm 0,00$ & $5,35 \pm 0,07$ & $5,42 \pm 0,09 \mathrm{a}$ \\
$\mathrm{A} 3$ & $5,35 \pm 0,07$ & $5,35 \pm 0,07$ & $5,35 \pm 0,05 \mathrm{~b}$ \\
$\mathrm{~A} 4$ & $5,30 \pm 0,14$ & $5,15 \pm 0,07$ & $5,22 \pm 0,12 \mathrm{c}$ \\
$\mathrm{A} 5$ & $5,25 \pm 0,07$ & $5,05 \pm 0,07$ & $5,15 \pm 0,12 \mathrm{c}$ \\
\hline $\begin{array}{c}\text { Rata- } \\
\text { rata }\end{array}$ & $5,39 \pm 0,15$ a & $5,28 \pm 0,17 \mathrm{~b}$ \\
\hline Keterangan & $:$ & Nilai rata-rata yang diikuti oleh \\
\multicolumn{4}{c}{ huruf yang sama pada kolom yang } \\
& sama menunjukkan perbedaan tidak \\
& nyata pada Uji Duncan (P>0,05)
\end{tabular}

Hal ini menunjukkan semakin lama perendaman dengan air perasan belimbing wuluh maka derajat keasaman $(\mathrm{pH})$ ikan tongkol akan semakin menurun sehingga menyebabkan daging ikan tongkol memiliki pH lebih asam (rendah), diduga hal tersebut disebabkan semakin banyaknya jumlah asam yang terserap ke dalam daging ikan tongkol seiring lamanya perendaman. Tabel 2 menunjukkan nilai rata-rata lama penyimpanan tertinggi diperoleh pada perlakuan P1 yaitu sebesar 5,39 , sedangkan nilai rata-rata terendah pada perlakuan P2 yaitu sebesar 5,28. Semakin lama penyimpanan derajat keasaman $(\mathrm{pH})$ ikan tongkol juga mengalami penurunan, Penurunan ini disebabkan oleh aktivas enzim yang terdapat pada daging ikan. Ilyas (1983), menyatakan pada proses glikolisis, enzim sangat berperan sampai terbentuknya asam laktat. Hal ini menyebabkan kandungan asam laktat meningkat seiring lamanya penyimpanan.

\section{Uji Total Mikroba}

Hasil sidik ragam menunjukkan bahwa interaksi antar kedua perlakuan berpengaruh nyata $(\mathrm{P}<0,05)$. Pada perlakuan lama perendaman dan lama penyimpanan berpengaruh nyata $(\mathrm{P}<0,05)$ terhadap total mikroba ikan tongkol yang direndam dalam air perasan belimbing wuluh

Tabel 3. Nilai rata-rata Total mikroba ikan tongkol yang direndam dalam air perasan belimbing wuluh

\begin{tabular}{ccc}
\hline Perlakuan & $\begin{array}{c}\text { Total Mikroba } \\
(\mathrm{Log} \mathrm{cfu} / \mathrm{g})\end{array}$ & $\begin{array}{c}\text { Total Mikroba } \\
(\mathrm{cfu} / \mathrm{g})\end{array}$ \\
\hline A1P1(0 menit;3 jam) & $5,34 \pm 0,09 \mathrm{a}$ & $2.2 \times 10^{5}$ \\
A2P1(2 menit;3 jam) & $4,39 \pm 0,01 \mathrm{ab}$ & $2.4 \times 10^{4}$ \\
A3P1(4 menit;3 jam) & $4,10 \pm 0,04 \mathrm{ab}$ & $1.3 \times 10^{4}$ \\
A4P1(6 menit;3 jam) & $4,03 \pm 0,04 \mathrm{ab}$ & $1.1 \times 10^{4}$ \\
A5P1(8 menit;3 jam) & $4,02 \pm 0,02 \mathrm{ab}$ & $1 \times 10^{4}$ \\
A1P2(0 menit;6 jam) & $5,75 \pm 0,07 \mathrm{a}$ & $5.6 \times 10^{5}$ \\
A2P2(2 menit;6 jam) & $4,90 \pm 0,79 \mathrm{ab}$ & $1.6 \times 10^{5}$ \\
A3P2(4 menit;6 jam) & $4,28 \pm 0,02 \mathrm{ab}$ & $1.9 \times 10^{4}$ \\
A4P2(6 menit;6 jam) & $4,20 \pm 0,28 \mathrm{ab}$ & $1.3 \times 10^{4}$ \\
A5P2(8 menit;6 jam) & $3,88 \pm 0,04 \mathrm{~b}$ & $7.7 \times 10^{3}$ \\
\hline
\end{tabular}

Keterangan : Nilai rata-rata yang diikuti oleh huruf yang sama pada kolom yang sama menunjukkan perbedaan tidak nyata pada Uji Duncan $(\mathrm{P}>0,05)$

Tabel 3 menunjukkan Total mikroba yang dihasilkan dipengaruhi lama perendaman dan lama penyimpanan. Semakin lama perendaman dengan air perasan belimbing wuluh maka total mikroba ikan tongkol akan semakin menurun. Kondisi asam pada ikan tongkol mempunyai peranan yang besar dalam menghambat aktifitas mikroba. Dinding sel bakteri bersifat permeable (memiliki kemampuan dalam menembus suatu sel), meningkatnya kandungan asam seiring lama perendaman mengakibatkan sifat permeable bakteri hilang sehingga aktifitas mikroba terhambat. Sejalan dengan hasil penelitian derajat keasaman $(\mathrm{pH})$ yang 
diperoleh, penurunan total mikroba tersebut berkaitan dengan semakin tingginya asam dan semakin rendahnya $\mathrm{pH}$ ikan tongkol, sejalan dengan semakin lamanya perendaman. Seiring lama penyimpanan total mikroba mengalami peningkatan. Diduga karena adanya aktifitas bakteri yang bersifat asidofil yaitu kelompok mikroba yang dapat hidup pada pH 2,5-5,5 (suasana asam).

Berdasarkan SNI 01-2779.1-2006 total mikroba pada ikan segar maksimal 5 x $10^{5} \mathrm{cfu} / \mathrm{g}$. Namun total mikroba pada perlakuan A1P2 yaitu sebesar 5,75 log $\mathrm{cfu} / \mathrm{g}$ atau $5,6 \times 10^{5} \mathrm{cfu} / \mathrm{g}$, total mikroba ikan tersebut berada diatas batas SNI untuk persyaratan mutu dan keamanan pangan ikan segar, sehingga tidak layak konsumsi.

\section{Uji Total Volatil Base}

Hasil sidik ragam menunjukkan bahwa perlakuan lama perendaman dan lama penyimpanan berpengaruh nyata $(\mathrm{P}<0,05)$, sedangkan interaksi antar kedua perlakuan tidak berpengaruh nyata $(\mathrm{P}>0,05)$ terhadap TVB ikan tongkol yang direndam dalam air perasan belimbing wuluh.

Tabel 4 menunjukkan nilai rata-rata lama perendaman total volatil base tertinggi pada perlakuan A1 yaitu sebesar $25,43 \mathrm{mg} \mathrm{N} / 100 \mathrm{~g}$, sedangkan nilai ratarata terendah pada perlakuan A5 yaitu sebesar 18,28 mg N/100g. Hal tersebut menunjukkan bahwa semakin lama perendaman maka TVB ikan tongkol yang dihasilkan akan semakin menurun.

Penurunan TVB berkaitan dengan semakin menurun total mikroba ikan tongkol dan sejalan dengan semakin rendahnya $\mathrm{pH}$ dan semakin tingginya asam pada ikan tongkol seiring lamanya perendaman. Kondisi asam menyebabkan aktifitas bakteri proteolitik terhambat.

Khairina (1995), menyatakan peningkatan kadar TVB terjadi karena adanya kerja bakteri proteolitik yang memecah protein hingga memutuskan ikatan peptida menjadi ikatan peptida yang pendek dan asam amino terurai menjadi senyawa amin dan amonia yang memberikan bau tajam (amis).

Tabel 4. Nilai Rata-rata Total volatil base ikan tongkol yang direndam dalam air perasan belimbing wuluh

\begin{tabular}{cccc}
\hline \multirow{2}{*}{$\begin{array}{c}\text { Lama } \\
\text { Perend } \\
\text { aman }\end{array}$} & \multicolumn{2}{c}{ Lama Penyimpanan } & Rata-rata \\
\cline { 2 - 3 } & $\mathrm{P} 1$ & $\mathrm{P} 2$ & \\
\hline $\mathrm{A} 1$ & $20,75 \pm 0,27$ & $30,10 \pm 0,12$ & $25,43 \pm 5,40 \mathrm{a}$ \\
$\mathrm{A} 2$ & $18,69 \pm 2,74$ & $22,54 \pm 1,59$ & $20,61 \pm 2,88 \mathrm{~b}$ \\
$\mathrm{~A} 3$ & $18,14 \pm 2,80$ & $21,57 \pm 0,40$ & $19,86 \pm 2,56 \mathrm{~b}$ \\
$\mathrm{~A} 4$ & $16,96 \pm 1,70$ & $20,97 \pm 0,96$ & $18,96 \pm 2,57 \mathrm{~b}$ \\
A5 & $16,28 \pm 0,97$ & $20,28 \pm 0,01$ & $18,28 \pm 2,37 \mathrm{~b}$ \\
\hline Rata- & $18,16 \pm 2,19 \mathrm{a}$ & $23,09 \pm 3,8 \mathrm{~b}$ & \\
rata & & & \\
\hline
\end{tabular}

Keterangan : Nilai rata-rata yang diikuti oleh huruf yang sama pada kolom yang sama menunjukkan perbedaan tidak nyata pada Uji Duncan $(\mathrm{P}>0,05)$

Tabel 4 menunjukkan nilai rata-rata lama penyimpanan TVB tertinggi diperoleh pada perlakuan P2 yaitu sebesar 23,09 mg N/100g, sedangkan nilai ratarata terendah perlakuan $\mathrm{P} 1$ yaitu sebesar $18,16 \mathrm{mg} N / 100 \mathrm{~g}$. Hal ini menunjukkan semakin lama penyimpanan TVB ikan tongkol mengalami peningkatan. Ozogul (2000) menyatakan bahwa total volatil base pada bahan pangan berbanding lurus dengan aktivitas mikroorganisme, yang mana total mikroba akan meningkat dengan adanya peningkatan suhu dan lama penyimpanan.

Sedangkan semakin lama penyimpanan TVB ikan tongkol mengalami peningkatan. Ozogul (2000) menyatakan bahwa total volatil base pada bahan pangan berbanding lurus dengan aktivitas mikroorganisme. Ozogul (2000), juga menyatakan penurunan $\mathrm{pH}$ akan mengaktifkan enzim katepsin yang mampu menguraikan senyawa-senyawa yang bersifat volatil seiring semakin lamanya penyimpanan.

Nurjanah et al., (2004) menyebutkan bahwa ikan termasuk sangat segar apabila nilai TVB kurang dari $10 \mathrm{mg} \mathrm{N} / 100$ g. Ikan dengan nilai 
TVB antara 10-20 mg N/100 g masuk dalam kriteria segar. Nilai TVB antara 20$30 \mathrm{mg} \quad \mathrm{N} / 100 \mathrm{~g}$ merupakan batas penerimaan ikan untuk dikonsumsi sedangkan jika nilai TVB lebih dari 30 mg N/100g termasuk ikan busuk.

\section{Uji Sensoris}

Uji sensoris ikan tongkol dilakukan dengan uji skoring (Hadiwiyoto 1993) terhadap warna, bau, tekstur dan sisik, keadaan mata, insang, dan lendir permukaan badan serta penerimaan keseluruhan dengan uji hedonik terhadap ikan tongkol. Skor atau penilaian menurut
(SNI 01-2729.1-2006) kriteria kesegaran ikan yaitu Segar (nilai 7-8), Agak segar (nilai 5-6), Tidak segar (nilai 1-4).

Hasil sidik ragam menunjukkan bahwa interaksi antar kedua perlakuan berpengaruh nyata $(\mathrm{P}<0,05)$ terhadap warna, bau, insang, lendir permukaan badan, dan penerimaan keseluruhan, serta tidak berpengaruh nyata $(\mathrm{P}>0,05)$ terhadap keadaan mata, tekstur dan sisik ikan tongkol yang direndam dalam air perasan belimbing wuluh. Nilai rata-rata uji sensoris dapat dilihat pada Tabel 5.

Tabel 5. Nilai rata-rata uji sensoris terhadap warna, bau, tekstur dan sisik,keadaan mata, insang, lendir permukaan badan, dan penerimaan keseluruhan ikan tongkol yang direndam dalam air perasan belimbing wuluh

\begin{tabular}{|c|c|c|c|c|c|c|c|}
\hline \multirow{2}{*}{$\begin{array}{c}\text { Perlakuan } \\
\text { (lama } \\
\text { perendaman;lama } \\
\text { penyimpanan) }\end{array}$} & \multicolumn{7}{|c|}{ Uji Sensoris } \\
\hline & warna & $\overline{\text { bau }}$ & $\begin{array}{c}\text { tekstur } \\
\text { Sisik }\end{array}$ & mata & insang & $\begin{array}{c}\text { lendir } \\
\text { permukaan }\end{array}$ & $\begin{array}{l}\text { Penerimaan } \\
\text { keseluruhan }\end{array}$ \\
\hline $\begin{array}{c}\text { A1P1 } \\
(0 \text { menit;3 jam })\end{array}$ & $7,40 \mathrm{a}$ & $6,60 \mathrm{a}$ & $6,60 a$ & $7,20 \mathrm{a}$ & $7,20 \mathrm{a}$ & $7,20 \mathrm{a}$ & $5,80 \mathrm{ab}$ \\
\hline $\begin{array}{c}\text { A2P1 } \\
(2 \text { menit;3 jam) }\end{array}$ & $7,00 \mathrm{ab}$ & $7,20 \mathrm{a}$ & $6,60 \mathrm{a}$ & $6,60 \mathrm{a}$ & $7,60 \mathrm{a}$ & $7,20 \mathrm{a}$ & $6,20 \mathrm{ab}$ \\
\hline $\begin{array}{c}\text { A3P1 } \\
\text { (4 menit;3 jam) }\end{array}$ & $6,60 \mathrm{ab}$ & $7,20 \mathrm{a}$ & $6,40 \mathrm{a}$ & $6,20 \mathrm{a}$ & $7,60 \mathrm{a}$ & $7,40 \mathrm{a}$ & $6,40 \mathrm{ab}$ \\
\hline $\begin{array}{c}\text { A4P1 } \\
\text { (6 menit;3 jam) }\end{array}$ & $5,47 \mathrm{ab}$ & $7,40 \mathrm{a}$ & $5,27 \mathrm{a}$ & $4,95 \mathrm{a}$ & $7,40 \mathrm{a}$ & $7,60 \mathrm{a}$ & $7,60 \mathrm{a}$ \\
\hline $\begin{array}{c}\text { A5P1 } \\
\text { (8 menit;3 jam) }\end{array}$ & $5,47 \mathrm{ab}$ & $7,40 \mathrm{a}$ & $5,20 \mathrm{a}$ & $4,93 \mathrm{a}$ & $7,20 \mathrm{a}$ & $7,60 \mathrm{a}$ & $6,20 \mathrm{ab}$ \\
\hline $\begin{array}{c}\text { A1P2 } \\
\text { (0 menit;6 jam) }\end{array}$ & $3,93 b$ & $3,53 b$ & $3,67 \mathrm{a}$ & $6,27 \mathrm{a}$ & $3,80 \mathrm{~b}$ & $4,07 b$ & $3,53 b$ \\
\hline $\begin{array}{c}\text { A2P2 } \\
(2 \text { menit } ; 6 \text { jam })\end{array}$ & $6,00 \mathrm{ab}$ & $7,00 \mathrm{a}$ & $5,80 \mathrm{a}$ & $5,60 \mathrm{a}$ & $7,40 \mathrm{a}$ & $7,00 \mathrm{a}$ & $6,07 a b$ \\
\hline $\begin{array}{c}\text { A3P2 } \\
\text { (4 menit;6 jam) }\end{array}$ & $5,27 \mathrm{ab}$ & $6,80 \mathrm{a}$ & $5,07 \mathrm{a}$ & $5,07 \mathrm{a}$ & $7,20 \mathrm{a}$ & $7,00 \mathrm{a}$ & $7,00 \mathrm{a}$ \\
\hline $\begin{array}{c}\text { A4P2 } \\
\text { (6 menit;6 jam) }\end{array}$ & 4,80ab & $7,20 \mathrm{a}$ & $4,67 \mathrm{a}$ & $4,53 \mathrm{a}$ & $7,00 \mathrm{a}$ & $7,20 \mathrm{a}$ & $7,20 \mathrm{a}$ \\
\hline $\begin{array}{c}\text { A5P2 } \\
\text { (8 menit;6 jam) }\end{array}$ & $4,47 \mathrm{ab}$ & $7,20 \mathrm{a}$ & $4,67 \mathrm{a}$ & $4,20 \mathrm{a}$ & $7,00 \mathrm{a}$ & $7,40 \mathrm{a}$ & $5,80 \mathrm{ab}$ \\
\hline
\end{tabular}

Keterangan : Nilai rata-rata yang diikuti oleh huruf yang sama pada kolom yang sama menunjukkan pengaruh tidak nyata pada Uji Duncan $(\mathrm{P}>0,05)$.

Skor warna

Skor bau

Skor tekstur dan sisik

: $8=$ Jernih spesifik jenisnya, dinding perut utuh, $7=$ Sedikit kurang cerah, dinding perut masih utuh, 5= Mulai pudar, dinding perut agak lunak, $3=$ Kusam, dinding perut lunak, $1=$ Warna sangat kusam, dinding perut sangat lunak.

: 8= Segar, Berbau ikan spesifik menurut jenisnya, 7= Agak segar, berbau ikan pada umumnya, 5= Bau amonia mulai timbul (sedikit berbau amis), 3= Bau amonia sangat kuat (amis), 1= Bau Busuk.

: $8=$ Tekstur padat sulit menyobek daging ikan, sisik padat tidak mudah lepas, $7=$ Tekstur agak padat, sisik tidak mudah lepas, 5= Tekstur agak lunak agak mudah menyobek daging ikan, sisik mudah lepas,3= Tekstur lunak, sisik sangat mudah lepas, $1=$ Tekstur sangat lunak sangat mudah menyobek daging ikan, sisik sangat mudah lepas. 
Skor mata

Skor insang

Skor lendir badan

\section{Warna}

Tabel 5 menunjukkan nilai rata-rata uji skoring warna tertinggi pada perlakuan A1P1(0 menit;3 jam) yaitu sebesar 7,40 (Jernih spesifik jenisnya, dinding perut utuh) sedangkan nilai rata-rata terendah pada perlakuan A1P2 (0 menit;6 jam) yaitu sebesar 3,93 (Kusam, dinding perut lunak). Hal tersebut menunjukkan ikan tongkol tanpa penambahan asam mengalami kemunduran mutu lebih cepat seiring lama penyimpanan. Warna ikan tongkol yang dihasilkan dipengaruhi lama perendaman dan lama penyimpanan. Semakin lama perendaman dengan air perasan belimbing wuluh seiring lama penyimpanan warna daging ikan tongkol akan semakin memudar.

Hal ini disebabkan semakin meningkatnya kandungan asam seiring lama perendaman menyebabkan protein terdenaturasi yaitu mengalami modifikasi atau mengalami perubahan struktur. Perubahan struktur atau muatan protein akan mengubah jarak antar serat-serat daging sehingga mempengaruhi kemampuan menyerap dan memantulkan cahaya sehingga warna daging ikan memudar.

\section{Bau}

Bau merupakan indikator kesegaran utama yang dilihat oleh konsumen saat membeli ikan segar. Tabel 5 menunjukkan nilai rata-rata uji skoring bau tertinggi pada perlakuan A4P1(6 menit;3 jam) dan A5P1(8 menit;3 jam) yaitu sebesar 7,40(, Berbau ikan spesifik menurut jenisnya), sedangkan nilai ratarata terendah pada perlakuan A1P2 (0 menit;6 jam) yaitu sebesar 3,53(Bau amonia sangat kuat (amis)).

Bau ikan tongkol yang dihasilkan dipengaruhi lama perendaman dan lama penyimpanan. Diduga zat asam pada belimbing wuluh dapat memperbaiki bau ikan tongkol selama perendaman seiring lama penyimpanan karena zat asam dapat mencegah terbentuknya senyawasenyawa sampingan hasil dari denaturasi protein yang menyebabkan bau amis.

Berdasarkan penelitian Aprianti (2011), asam dapat menyamarkan bau yang timbul dari ikan segar yang disebabkan oleh berkurangnya jumlah mikroba. Nilai uji sensoris bau yang dilakukan oleh panelis dengan perendaman dalam air perasan belimbing wuluh seiring dapat memperbaiki bau ikan tongkol. Penggunaan belimbing wuluh sebagai bahan pengawet alami dapat mencegah timbulnya bau amis ikan.

\section{Tekstur dan Sisik}

Tabel 5 menunjukkan penilaian panelis terhadap tekstur dan sisik ikan tongkol selama perendaman semakin menurun, sejalan dengan lama penyimpanan. Sedangkan perlakuan A2P2 yaitu sebesar 5,80 (Tekstur agak lunak agak mudah menyobek daging ikan, sisik mudah lepas). penilaian panelis meningkat, namun semakin lama perendaman seiring lama penyimpanan penilaian panelis terhadap uji skoring 
tekstur dan sisik ikan tongkol semakin menurun. Hal ini menunjukkan bahwa ikan tongkol yang direndam selama 2 menit dan disimpan selama 6 jam masih agak segar yaitu memiliki tekstur yang cukup padat dan sisik tidak mudah lepas.

Semakin lama perendaman tekstur ikan tongkol menjadi lebih lunak dan sisik mudah lepas diduga semakin banyak kandungan asam yang terserap ke dalam jaringan daging ikan. Borgstrom (1995) menyatakan bahwa adanya asam dalam daging ikan akan mendenaturasi protein yang dapat menyebabkan terjadinya koagulasi dan membebaskan air dan air pada daging ikan akan berkurang, sehingga daging ikan lebih lunak.

\section{Keadaan Mata}

Mata merupakan indikator kesegaran utama yang dilihat oleh konsumen saat membeli ikan segar. Tabel 5 menunjukkan semakin lama perendaman penilaian panelis terhadap keadaan mata ikan tongkol mengalami penurunan, hal ini disebabkan semakin banyak kandungan asam yang terserap sehingga mata ikan tongkol memutih seiring semakin lamanya penyimpanan.

\section{Insang}

Tabel 5 menunjukkan nilai rata-rata uji skoring insang tertinggi pada perlakuan A2P1(2 menit;3 jam) dan A3P1(4 menit;3 jam) yaitu sebesar 7,60 (Warna merah, tanpa adanya lendir), sedangkan nilai ratarata terendah pada perlakuan A1P2 (0 menit;6 jam) yaitu sebesar 3,80 (Warna merah coklat kehitaman atau abu-abu, tertutup lendir). Hal tersebut menunjukkan ikan tongkol tanpa penambahan asam mengalami kemunduran mutu lebih cepat seiring lama penyimpanan. Insang ikan tongkol yang dihasilkan dipengaruhi lama perendaman dan lama penyimpanan.

Semakin lama perendaman terlihat insang tongkol mengalami penurunan seiring lama penyimpanan. Nilai uji sensoris insang yang dilakukan oleh panelis dengan perendaman dalam air perasan belimbing wuluh membuat insang ikan tongkol lebih baik dari pada tanpa penambahan asam, diduga zat asam berperan sebagai bahan alami antibakteri yang dapat menghambat bakteri yang terdapat pada insang. Menurut Septiarni (2008), insang ikan termasuk organ tubuh yang paling rentan terhadap kebusukan dan cepat mengalami kebusukan dibanding organ tubuh lain karena akumulasi bakteri dalam jumlah tinggi pada insang.

\section{Lendir Permukaan Badan}

Tabel 5 menunjukkan nilai rata-rata uji skoring lendir permukaan badan tertinggi pada perlakuan A4P1(6 menit;3 jam) dan A5P1(8 menit;3 jam) yaitu sebesar 7,60 (Segar, lapisan lendir jernih dan transparan), sedangkan nilai rata-rata terendah pada perlakuan A1P2 (0 menit;6 jam) yaitu sebesar 4,07 (Lendir tebal menggumpal, mulai berubah warna putih, keruh). Hal tersebut menunjukkan ikan tongkol tanpa penambahan asam mengalami kemunduran mutu lebih cepat seiring lama penyimpanan.

Hal ini diduga karena zat asam dalam belimbing wuluh dapat membuat keadaan ikan menjadi asam sehingga aktifitas bakteri menjadi terhambat dan lendir yang terbentuk pada lapisan kulit dan permukaan badan ikan masih dalam kategori dapat diterima seiring lama penyimpanan.

Berdasarkan hasil lendir permukaan badan ikan tongkol terlihat semakin lama perendaman, maka semakin meningkat mutu ikan tongkol paramater lendir.. Semakin lama penyimpanan uji skoring lendir permukaan badan pada ikan tongkol mengalami penurunan. Namun, masih dalam kategori agak segar dengan lapisan lendir agak jernih dan belum adanya perubahan warna pada lapisan lendir. 


\section{Penerimaan Keseluruhan}

Berdasarkan data yang diperoleh tingkat kesukaan panelis terhadap ikan tongkol yang direndam dalam air perasan belimbing wuluh mengalami peningkatan. Tabel 55 menunjukkan nilai rata-rata uji hedonik penerimaan keseluruhan tertinggi pada perlakuan A4P1(6 menit;3 jam) yaitu sebesar 7,60 (suka), sedangkan nilai ratarata terendah pada perlakuan A1P2 (0 menit;6 jam) yaitu sebesar 3,53 (tidak suka). Berdasarkan hasil uji hedonik penerimaan keseluruhan ikan tongkol, terlihat ikan tongkol yang direndam dalam air perasan belimbing wuluh lebih disukai oleh panelis dari pada ikan tongkol tanpa penambahan asam.

Penerimaan keseluruhan ikan tongkol dipengaruhi oleh beberapa faktor seperti warna, bau, tekstur dan sisik, keadaan mata, lendir permukaan badan dan insang. Namun secara keseluruhan, ikan tongkol yang direndam dalam air perasan belimbing wuluh dengan lama waktu penyimpanan 3 jam hingga 6 jam masih dapat diterima oleh panelis.

\section{KESIMPULAN DAN SARAN}

\section{Kesimpulan}

Berdasarkan hasil penelitian ini dapat disimpulkan sebagai berikut :

1. Interaksi antara lama perendaman dan lama penyimpanan berpengaruh nyata $(\mathrm{P}<0,05) \quad$ terhadap karakteristik mikrobiologi (total mikroba) dan karakteristik sensoris (nilai skoring warna, bau, tekstur, insang, lendir permukaan badan dan nilai hedonik penerimaan keseluruhan) ikan tongkol, serta tidak berpengaruh nyata $(\mathrm{P}>0,05)$ terhadap karakteristik kimia (kadar air, nilai $\mathrm{pH}$, total volatil base) dan karakteristik sensoris (keadaan mata, tekstur dan sisik).

2. Berdasarkan karakteristik kimia, mikrobiologi, dan sensoris, produk ikan tongkol yang dapat diterima yaitu perlakuan lama perendaman 4 menit dengan lama penyimpanan 6 jam
(A3P2), memiliki kadar air 71,5\%, derajat keasaman 5,35, total mikroba $4,28 \mathrm{log} \mathrm{cfu} / \mathrm{g}$ atau $1.9 \times 10^{4} \mathrm{cfu} / \mathrm{g}$, total volatil base $21,57 \mathrm{mg} \mathrm{N} / 100 \mathrm{~g}$ dan nilai skor warna, bau, tekstur dan sisik, keadaan mata, insang, dan lendir permukaan badan yang dapat diterima oleh panelis serta penerimaan keseluruhan yang disukai.

\section{Saran}

Berdasarkan hasil penelitian ini disarankan untuk dilakukan penelitian terkait waktu penyimpanan untuk mengamati kemunduran mutu ikan tongkol yang direndam dalam air perasan belimbing wuluh diperpanjang lebih dari 6 jam.

\section{DAFTAR PUSTAKA}

Aminonatalina.2016. Pengaruh Pemberian Ekstrak Belimbing Wuluh (Averrhoa Bilimbi) Terhadap Berat Residu Formalin Ikan Tongkol (Euthynnus affinis) Berformalin. Enviro Scienteae, 160-167.

Aprianti, D. 2011. Aktivitas Antibakteri Ekstrak Biji Picung (Pangium edule Reinw) dan Pengaruhnya Terhadap Stabilitas Fisika Kimia, Mikrobiologi dan Sensori Ikan Kembung (Rastrelliger neglectus). Jakarta: UIN Syarif Hidayatullah.

Astarini, F.N.P. Burhan, R.Y.P. dan Yulvi, Z. 2010. Minyak Atsiri Dari Kulit Buah Citrus Grandis, Citrus Aurantium (L.) Dan Citrus Aurantifolia (Rutaceae) Sebagai Senyawa Antibakteri Dan Insektisida. Surabaya : Kimia Fmipa ITS.

Borgstorm, G. 1995. Prinsiples of Food Science. In The effect of Different Types of Orange Acid and Immersion Time on the Quality of Goldfish Naniura. Gina (Eds). Applied Science Publishing Ltd., London, p. 475-478. 
BSN.2006. Ikan Segar : SNI 01-2729.12006. Jakarta: Badan Standarisasi Nasional.

Deviyanti, P. N. 2015. Efektifitas Daun Kemangi (Ocinum sanctum L.) Sebagai Antibakteri Pada Ikan Kembung Lelaki (Rastrelliger kanagurta) Selama Penyimpanan Dingin. Jurnal Pengolahan Dan Bioteknologi Hasil Perikanan, Vol 4. No 3 Hal : 1-6.

Djaafar, T. F. 2007. Cemaran Mikroba pada Produk Pertanian, Penyakit yang Ditimbulkan, dan Pencegahannya . Yogyakarta: Balai Pengkajian Teknologi Pertanian.

Djuhanda.1981. Dunia Ikan. Bandung: Armico.

Effendi, S.2012. Teknologi Pengolahan Pangan dan Pengawetan Pangan. Bandung: Penerbit Alfabeta.

Gomez, K. A., and G. F. Cardoso.1995. Prosedur Statistik untuk Penelitian Pertanian. (Terjemahan). E. Syamsudin dan J. S. Baharsjah. UI Press, 698 hal.

Hariana.2006.Tumbuhan Obat dan Khasiatnya. Jakarta: Penebar Swadaya Wisma Hijau.

Jayanti, S., llza, M., \& Desmelati. 2012. Pengaruh Penggunaan Minuman Berkarbonasi Untuk Menghambat Kemunduran Mutu Ikan Gurami (Osphronemus Gouramy) Pada Suhu Kamar. Jurnal Perikanan dan Kelautan, 71-87.

Meliya. 2018. Kualitas Ikan Tongkol (Euthynnus affinis) dengan Pengawet Alami Ekstrak Daun Kemangi pada Variasi lama Perendaman.Surakarta:Universitas Muhammadiyah.

Nurjanah, Setyaningsih I., Sukarno., \& Muldani M. 2004. Kemunduran mutu ikannila merah (Oreochromis Sp.) selama penyimpanan pada suhu ruang. Buletin Teknologi Hasil Perikanan 7(1): 37-42

Ozogul.2000. Comparison of methods used for determination of total volatil basic nitrogen (TVB-N) in rainbow trout (Oncorhynchus mykiss). Turkey Journal Zoology 24: 113-120.

Pia, S. 2008. Aplikasi Minuman Ringan Berkarbonasi Dalam Menghambat Laju Mutu Ikan Nila (Oreochromis niloticus). Bogor: Fakultas Perikanan dan Ilmu Kelautan. Institut Pertanian Bogor.

Septiarni, T. 2008. Karakteristik Mutu Ikan Tenggiri (Scomberomorus commersonii) Di Kecamatan Manggar, Kabupaten Belitung Timur, Bogor: Fakultas Perikanan dan Ilmu Kelautan. Institut Pertanian Bogor.

Siti.2018. Efektivitas Ekstrak Bawang Putih Sebagai Pengawet Terhadap Daya Suka Suka Organoleptik Daging Boiler. Lampung: Universitas Lampung.

Yusni.2014. Pemanfaatan Belimbing Wuluh sebagai Pengawet Alami pada Ikan Teri Asin Kering. Jurnal Ilmiah Perikanan dan Kelautan, Volume II, Nomor 2. 